NOTICE: this is the author's version of a work that was accepted for publication in Materials Research Bulletin. Changes resulting from the publishing process, such as peer review, editing, corrections, structural formatting, and other quality control mechanisms may not be reflected in this document. Changes may have been made to this work since it was submitted for publication. A definitive version was subsequently published in Materials Research Bulletin, Vol. 47, Issue 1, 2012. DOI: 10.1016/j.materresbull.2011.09.017. 


\title{
Effect of characteristics of $(\mathrm{Sm}, \mathrm{Ce}) \mathrm{O}_{2}$ powder on the fabrication and performance of anode-supported solid oxide fuel cells
}

\author{
Na Ai ${ }^{\mathrm{a}, \mathrm{b}}$, Kongfa Chen ${ }^{\mathrm{b}}$, Shaomin Liu ${ }^{\mathrm{c}}$, Zhe Lï̈, Wenhui Su, ${ }^{\mathrm{a}, *}$, San Ping Jiang ${ }^{\mathrm{b}, *}$ \\ ${ }^{a}$ Center for Condensed Matter Science and Technology, Department of Physics, Harbin \\ Institute of Technology, Harbin 150001, PR China \\ ${ }^{\mathrm{b}}$ Fuels and Energy Technology Institute \& Department of Chemical Engineering, Curtin \\ University, Perth, WA 6102, Australia \\ ${ }^{\mathrm{c}}$ Department of Chemical Engineering, Curtin University, Perth, WA 6102, Australia
}

\begin{abstract}
Effect of characteristics of $\mathrm{Sm}_{0.2} \mathrm{Ce}_{0.8} \mathrm{O}_{1.9}$ (SDC) powder as a function of calcination temperature on the fabrication of dense and flat anode-supported SDC thin electrolyte cells has been studied. The results show that the calcination temperature has a significant effect on the particle size, degree of agglomeration, and sintering profiles of the SDC powder. The characteristics of SDC powders have a significant effect on the structure integrity and flatness of the SDC electrolyte film/anode substrate bilayer cells. The SDC electrolyte layer delaminates from the anode substrate for the SDC powder calcined at $600^{\circ} \mathrm{C}$ and the bilayer cell concaves towards the SDC electrolyte layer for the SDC powder calcined at $800^{\circ} \mathrm{C}$. When the calcinations temperature increased to $1000^{\circ} \mathrm{C}$, strongly bonded SDC electrolyte film/anode substrate bilayer structures were achieved. An open-circuit voltage (OCV) of $0.82-0.84 \mathrm{~V}$ and maximum power density of $\sim 1 \mathrm{~W} \mathrm{~cm}{ }^{-2}$ were obtained at $600^{\circ} \mathrm{C}$ using hydrogen as fuel and stationary air as the

\footnotetext{
* Corresponding authors.
}

Email addresses: s.jiang@curtin.edu.au (S.P. Jiang), suwenhui@hit.edu.cn (W.H. Su)
\end{abstract}


oxidant. The results indicate that the matching of the onset sintering temperature and maximum sintering rate temperature is most critical for the development of a dense and flat $\mathrm{Ni} / \mathrm{SDC}$ supported SDC thin electrolyte cells for intermediate temperature solid oxide fuel cells.

Keywords: A: anode-supported cells; B: electrochemical properties; C: sintering profile; D: solid oxide fuel cells; E: samaria doped ceria.

\section{Introduction}

The excessive and accelerated use of fossil fuels, especially coal, oil, and gas, in the past 100 years has triggered a global energy crisis, and carbon emission from power generation using fossil fuels is considered a key contributor to climate change and related environmental problems. Fuel cell is an energy conversion device to electrochemically convert the chemical energy of fuels such as hydrogen, methanol, ethanol, natural gas, and light hydrocarbons to electricity with inherently high efficiency. Among various types of fuel cells, solid oxide fuel cell (SOFC) is the most efficient and much less polluting power-generating technology, and is a potential and viable candidate to moderate the fast increase in power requirements and to minimize the impact of the increased power consumption on the environment. To accelerate the commercialization of SOFC technologies, it is necessary to reduce the operating temperature of SOFCs from conventional $1000^{\circ} \mathrm{C}$ to intermediate temperature range of $600-800^{\circ} \mathrm{C}$ to increase the long-term stability, widen the selection of interconnect and heat exchanger materials, and use low cost fabrication processes[1-4]. One challenge associated with lowering the operating temperature is the significant increase of the electrolyte resistance. For example, for the state-of-the-art yttria-stabilized zirconia (YSZ) electrolyte materials, 
the oxygen ion conductivity is $0.16 \mathrm{~S} \mathrm{~cm}^{-1}$ at $1000^{\circ} \mathrm{C}$ and decreases to $8.73 \times 10^{-3} \mathrm{~S} \mathrm{~cm}^{-1}$ when temperature is reduced to $600^{\circ} \mathrm{C}$ [5]. This problem, however, can be mitigated by developing new electrolyte materials with high ionic conductivities $[6,7]$ and/or by reducing the thickness of electrolyte to several or tens of microns [8-11].

Doped ceria such as samaria doped ceria (SDC) is widely used as candidate electrolyte materials for low to intermediate temperature SOFC, because of their much higher ionic conductivity compared to that of the YSZ electrolyte materials $[12,13]$. High SOFC performance has been obtained at reduced temperatures by use of anode-supported doped ceria electrolyte films [14-22]. For the anode substrate/electrolyte film bilayer structure, it is critical to match carefully sintering profiles of both the anode substrates and the thin electrolyte layer, otherwise the sintering mismatch will cause intolerant bending and/or cracking of the structure during co-sintering [23].

The structural integrity of the anode-supported cells depends strongly on the characteristics of the starting powders and the sintering profile of both the anode substrate and electrolyte layers. The shrinkage profile of the anode substrates could be manipulated by using different amounts of pore-formers [24, 25], composite pore-formers [26], the pre-sintering temperatures of anode substrate [27, 28], variation of the packing density of anode substrate [29], or changing the particle size of starting powder of anode [30]. In addition, the sintering profiles, sintered density of electrolyte film and cell flatness are also significantly affected by the characteristics of electrolyte slurry such as ink solids loading [27, 31] and the starting powder [32]. The characteristics of the starting electrolyte powders not only affect the sintering profile but also affect the resultant density of the film. Leng et al. [32] showed that electrolyte film 
made from nano-sized YSZ powder is unable to be fully densified at $1400{ }^{\circ} \mathrm{C}$ but the submicron sized powder can produce dense and pore-free YSZ films. The low green density of the nano-sized YSZ powder and the significant difference in the sintering behavior of the nano-sized YSZ electrolyte layer and the Ni/YSZ anode substrate are the main reasons for the poor quality YSZ electrolyte film obtained. It is known that the ultrafine particle size, particle shape, green density and aggregation of the precursor powders all affect the morphology and sinterability of the powders, thus greatly influence the density of the sintered electrolyte film [33, 34]. Song et al.[35] showed that the bending of anode-supported cells could be avoided by placing a zirconia plate weight over the bilayer cells during co-sintering. However, large internal stress could be accumulated within the bilayer structure due to the mismatch of the sintering profiles and the release of the stress during cell operation and testing can cause the formation of cracks across the YSZ film and subsequent failure of cells [29].

The characteristics of the starting powders plays an important role in the sintering profiles and is critical for the structural integrity of the anode supported cells. However, despite the significant information on the effect of the characteristics of the starting powders on the sintering process and performance of anode-supported cells based on YSZ electrolyte [24-28, 31, 32], there is relatively little information in the open literature on the effect of the characteristics of the ceria-based powders on the sintering profile and structure integrity of the anode-supported ceria-based electrolyte cells. In this paper, the characteristics of the morphology and particle size distribution of SDC powder as a function of calcination temperatures were studied and their effects on the sintering profile and the structure integrity of anode-supported SDC thin film cells by slurry spin coating were studied. The results show that dense and flat anode-supported 
thin SDC electrolyte cells can be obtained by careful control of the characteristics of the SDC powder by combination of calcination and mechanical ball milling treatments.

\section{Experimental}

$\mathrm{Sm}_{0.2} \mathrm{Ce}_{0.8} \mathrm{O}_{1.9}$ (SDC) powder was prepared from $\mathrm{Sm}_{2} \mathrm{O}_{3}$ (analytical reagent, Shanghai Nonferrous Metals), HNO $_{3}$ (A. R., Shanghai Nonferrous Metals), $\mathrm{Ce}\left(\mathrm{NO}_{3}\right)_{3} \cdot 6 \mathrm{H}_{2} \mathrm{O}$ (A. R., Shanghai Nonferrous Metals) and glycine (A. R., Shanghai Fine Chemical Technology Institute) by a glycine-nitrate process (GNP) [36]. The molar ratio of glycine to metal cations was $1.5: 1$. The as-prepared powder was calcined at 600 , 800 and $1000{ }^{\circ} \mathrm{C}$ for $2 \mathrm{~h}$ and was denoted as SDC600, SDC800 and SDC1000, respectively. SDC powders were ball milled with ethanol media, and the ball milling was stopped every $4 \mathrm{hrs}$ to collect the powder and the particle size distributions were measured with a laser particle size analyzer (Mastersizer 2000, Malvern Instrument, UK). To characterize the sintering behavior of the electrolyte powder, sintering shrinkages of disc-type samples were measured with a dilatometer (DIL402C/3/G, Netzsch) from 50 to $1300{ }^{\circ} \mathrm{C}$ at a heating rate of $5{ }^{\circ} \mathrm{C} \mathrm{min}^{-1}$. The discs, which were 6 $\mathrm{mm}$ in diameter and $0.4 \mathrm{~mm}$ in thickness, were prepared by die pressing SDC powders at an apparent pressure of $410 \mathrm{MPa}$.

Anode substrate powder was prepared from NiO, SDC800 and wheat flour in a weight ratio of 54.2: 29.2: 16.6, followed by pestle and mortar for $2 \mathrm{~h}$. The $\mathrm{NiO}$ powder was prepared by precipitation method, followed by calcined at $400{ }^{\circ} \mathrm{C}$ for $2 \mathrm{~h}$ [37]. The anode powder was then compacted into pellets of $13 \mathrm{~mm}$ in diameter and $0.7 \mathrm{~mm}$ in thickness, followed by pre-sintered at $950{ }^{\circ} \mathrm{C}$ for $2 \mathrm{~h}$ to form the anode substrates. The sintering profile of the anode substrate was also measured with the dilatometer from 50 to $1300{ }^{\circ} \mathrm{C}$ at a heating rate of $5{ }^{\circ} \mathrm{C} \min ^{-1}$. 
SDC600, SDC800 and SDC1000 powders were ball milled for $20 \mathrm{~h}$ as the starting electrolyte powders and were applied on to the pre-fired anode substrates by slurry spin coating [34]. The SDC thin film/anode substrate bilayers structures were co-sintered at $1400{ }^{\circ} \mathrm{C}$ for $4 \mathrm{~h}$ in air. $\mathrm{Ba}_{0.5} \mathrm{Sr}_{0.5} \mathrm{Co}_{0.8} \mathrm{Fe}_{0.2} \mathrm{O}_{3-\delta}$ (BSCF) cathode layers were then deposited on the SDC electrolyte side of the cells by slurry coating, followed by sintering at $1050{ }^{\circ} \mathrm{C}$ for $4 \mathrm{~h}$. The details for the cell fabrication were similar to that in previous works [21, 34]. The anode substrates were reduced in situ by feeding hydrogen

at $600{ }^{\circ} \mathrm{C}$. During cell testing, $50 \mathrm{~mL} \mathrm{~min}^{-1}$ dry hydrogen was used as the fuel, while the cathode was exposed to the stationary ambient air. The performance and ac impedance responses of the cell were measured with electrochemical interface Solartron SI 1287 and impedance analyzer SI 1260 at different temperatures.

The crystalline structures of the powders were identified at room temperature by powder X-ray diffractometer (XRD, Bede D1 X-ray Diffractometer) using Cu $\mathbf{K}_{\boldsymbol{\alpha}}$ radiation. The grain size and morphology of the SDC powder were determined by a transmission electron microscopy (TEM, JEOL JEM-1200EX). The microstructure of the SDC powder was detected by a scanning electron microscope (SEM, Hitachi S-570). The surface of electrolyte films and cross-sections of the cells were characterized by SEM.

\section{Results and discussion}

\subsection{Phase and particle size characterization of SDC powder}

Fig. 1 shows XRD patterns of the SDC powders calcined at 600,800 and $1000^{\circ} \mathrm{C}$. All the powders show the desired cubic fluorite structure. The broadening of the XRD peaks indicates nanocrystalline nature of the powder. The peaks become narrower with 
increasing calcination temperature. The crystallite sizes could be estimated from the full width at half maximum of the strong reflection (111) using the Scherrer formula:

$$
\mathrm{D}=0.89 \lambda /(\beta \cos \theta)
$$

where $D$ is the average crystalline size, $\beta$ is the full-width at half height of the peak of which the effect from the XRD instrument has been deducted, $\lambda$ is the wavelength of $\mathrm{X}$-ray and $\theta$ is the diffraction angle of the peak. The estimated average crystallite size is $14 \mathrm{~nm}$ after calcination at $600{ }^{\circ} \mathrm{C}$, increasing to 31 and $86 \mathrm{~nm}$ after calcination at 800 and $1000{ }^{\circ} \mathrm{C}$, respectively. The average grain size of the nanoparticles increases continuously during calcination in order to minimize the high surface energy of the nanoparticles [38].

The particle size and morphology of the SDC nanoparticles were characterized by TEM, and the micrographs are shown in Fig. 2. The powders were dispersed in ethanol media by ultrasonic treatment followed by dropping on $\mathrm{Cu}$ foil. The particles exhibit almost spherical shape. The particle size of the SDC powders calcined at 600,800 and $1000{ }^{\circ} \mathrm{C}$ was estimated as $9-12 \mathrm{~nm}, 20-35 \mathrm{~nm}$ and $25-80 \mathrm{~nm}$, respectively, in good agreement with the calculated results from the XRD (Fig. 1). It shows a significant agglomeration of the nanosized SDC particles calcined at 600 and $800{ }^{\circ} \mathrm{C}$ (Fig. 2a and b). The significant agglomeration is due to the tendency of the nano-sized particles to minimize the high surface energy [38]. This is also supported by the observation for the SDC powders calcined at $1000^{\circ} \mathrm{C}$, the crystalline size increases, leading to the significant reduction in agglomeration (Fig. 2c).

Fig. 3 shows the SEM micrograph of the as-prepared SDC800 powder. The SDC powder is characterized by large foam-like agglomerates in the 4-20 $\mu \mathrm{m}$ in diameter. The formation of a highly porous and foam-like agglomerate structure is primarily 
resulted from a large amount of gases released by the redox reaction during GNP synthesis processes [36]. The foam-like agglomerates are consisted of nano-size crystalline particles as shown in Fig. 2. The loosely bonded and porous agglomerate powder prepared by GNP has been shown to be beneficial for the fabrication of thin electrolyte film supported on porous anode substrate by dry pressing [39]. The soft agglomerates could be broken up by the high compaction pressure and thus a high packing density could be obtained after the compaction process [15, 29, 40]. However, the direct use of the loosely packed foam like powders as the starting materials for the slurry based fabrication methods such as slurry spin coating may result in low packing green density of the thin layer, which in turn could lead to the porous electrolyte films after sintering at high temperature [34].

It is important to establish the relationship between the characteristics of the powder and the density of the SDC electrolyte layers. Therefore, the as-calcined SDC powders were treated by mechanical ball milling, and the particle size distribution was measured as a function of the ball milling time. Fig. 4 shows an example of the particle size distributions of SDC800 as a function of ball-milling time. The as-calcined SDC800 powder before ball milling treatment shows a rather symmetric and narrow distribution with a maximum at $\sim 6 \mu \mathrm{m}$. After ball milling for $4 \mathrm{~h}$, there is a significant change in the particle size and particle size distribution. This is indicated by the significant reduction in particles size and the formation of a new peak at $0.2 \mu \mathrm{m}$. The SDC800 powders after ball milling treatment is characterized by a bimodal distribution. With continuing ball milling treatment, the position of peak at $1 \mu \mathrm{m}$ is gradually shifted to lower value and the peak intensity at $0.2 \mu \mathrm{m}$ increases. After ball milling for $20 \mathrm{~h}$, the powder shows a strong peak at $0.2 \mu \mathrm{m}$ and a weak one at $1 \mu \mathrm{m}$, and the particle 
distribution range is reduced to $0.06-3.0 \mu \mathrm{m}$. The significant decrease in particle size and particle size distribution demonstrates that the degree of agglomeration in the as-calcined SDC powders has been significantly reduced by the ball-milling treatment and ball-milling is effective to break the agglomerated powders. However, the particle size after ball milling for $20 \mathrm{~h}$ is still much larger than the crystallite size (see Figs. 1 and 2). This suggests that there still exist large amount of agglomerates after the ball-milling treatment. With a further increase in the ball-milling time, the effect of the ball-milling on the reduction in the agglomerate size became smaller. Thus in this study all the as-calcined SDC powders were ball milled for $20 \mathrm{~h}$ prior to the slurry spinning coating fabrication process.

The particle size distributions of the SDC powders calcined at different temperatures after ball milling for $20 \mathrm{~h}$ are shown in Fig. 5. All the three SDC powders show characteristics of a bimodal particle size distribution with similar peaks at 0.2 and $1 \mu \mathrm{m}$. The particle size range was $0.06 \sim 3 \mu \mathrm{m}$. As the calcination temperature increases, the peak at $1 \mu \mathrm{m}$ decreases while the peak at $0.2 \mu \mathrm{m}$ increases, although the difference is not significant. This result is interesting as it indicates that calcination at a higher temperature leads to a smaller secondary particle size after ball milling. However, this can be explained by the observations that calcination at a higher temperature results in a larger crystallite size and thus reduced tendency to form agglomerates (Fig. 1 and 2). Therefore, ball-milling treatment will be more effective to break the agglomerates with large crystalline particles as compared to that with fine crystalline particles. The characteristics of particle size distribution will have a significant effect on the sintering behavior of the powders, and subsequently on the microstructure and performance of the thin electrolyte film cells [41]. 


\subsection{Sintering shrinkage and co-sintering behavior}

Sintering behavior of SDC powder and NiO/SDC anode substrates was studied to estimate the effect of calcination temperature on the sintering profiles of SDC powder. Fig. 6 shows the sintering behavior of the SDC samples and the anode substrate in the temperature range from 50 to $1300{ }^{\circ} \mathrm{C}$. The anode substrates were pre-fired at $950^{\circ} \mathrm{C}$ for $2 \mathrm{~h}$. The samples firstly undergo a slight expansion followed by shrinkage as the sintering temperature increases (Fig. 6a). The shrinkage onset temperature of the SDC powders changes significantly with the calcination temperature of the powder. The shrinkage onset temperature of SDC600 was $556^{\circ} \mathrm{C}$ and increased to $843^{\circ} \mathrm{C}$ for the SDC powder calcined at $1000^{\circ} \mathrm{C}$. But the overall linear shrinkage percentage decreases with the increase in the powder calcination temperature. In the case of anode substrate pre-fired at $950^{\circ} \mathrm{C}$, the shrinkage onset temperature is $920^{\circ} \mathrm{C}$ and the shrinkage is high. The high shrinkage of anode substrate is most likely related to the thick Ni/SDC substrates. The linear shrinkage is related to the initial packing density of the compacts. Thus more pores in the compacted specimens with lower density would lead to larger shrinkage.

Another important parameter of the sintering profile is the shrinkage rate (Fig. 6b). The maximum shrinkage rate or the sintering peak of the SDC powders increases with the calcination temperature. Ma and Lim [42] studied the sintering process of alumina powders and showed that during sintering, alumina powders firstly undergo local densification within agglomerates, leading to the formation of channel like pores and their evolution into isolated pores, and eventually the elimination of the pores by further sintering. The earlier occurrence of the shrinkage peak indicates the sintering and densification process between the agglomerates. The maximum shrinkage rate occurred 
at temperatures of 887,992 , and $1258^{\circ} \mathrm{C}$ for the SDC powders calcined at 600,800 and $1000^{\circ} \mathrm{C}$, respectively. In the case of anode substrate, the maximum shrinkage occurred at $1200^{\circ} \mathrm{C}$, close to the SDC powder calcined at $1000^{\circ} \mathrm{C}$. The parameters of the sintering profiles of SDC powder and anode substrate are given in Table 1.

The thermal or sintering compatibility of the SDC powder and the anode substrate was examined in co-sintered anode-supported SDC bilayer structure. The anode-supported SDC bilayer structures were co-sintered at $1400^{\circ} \mathrm{C}$ for $4 \mathrm{~h}$ at an average heating rate of $\sim 3{ }^{\circ} \mathrm{C} \min ^{-1}$ and SDC powders that were ball milled for $20 \mathrm{~h}$ were prepared onto NiO/SDC anode substrates by slurry spin coating. Fig. 7 shows the optical photos of the anode-supported SDC bilayer cells after co-sintering. The bilayer samples show different morphologies and appearance with the SDC powders. As the anode substrates were the same for all the samples, the significant difference in the morphologies of the bilayer cells is evidently due to the differences in the calcination temperature of the starting SDC powder. For the bilayer sample with SDC600, a great part of the electrolyte films delaminated from the anode substrate, and the anode substrate was flat. In the case of cells with SDC800 and SDC1000 powders, there is no electrolyte delamination, indicating the good adhesion between the anode substrate and the SDC layer. However, the bilayer cell with SDC800 electrolyte thin film concaved towards the electrolyte. The flat bilayer structure was obtained on the cells with SDC1000 electrolyte powder. The results demonstrate that the SDC1000 electrolyte film appears to match well thermally with the anode substrate during co-sintering process.

Fig. 8 shows schematically the relationship between the sintering parameters of the SDC powder and anodes substrates and the morphology and structure of the anode/SDC 
bilayer cells. As shown in Fig. 6, the onset shrinkage temperature and maximum shrinkage rate temperature, $\mathrm{T}_{\text {Shrinkage }}$ and $\mathrm{T}_{\text {Shrinkage rate }}$ of SDC600 are 556 and $887^{\circ} \mathrm{C}$, respectively, which are significantly lower than the corresponding temperatures of 920 and $1200^{\circ} \mathrm{C}$ for the anode substrate. This indicates that the SDC600 electrolyte layer started shrinkage and reached the maximum shrinkage rate, much earlier than that of the underneath anode substrates. For example, the SDC600 electrolyte layer already shrunk $5.2 \%$ at $920^{\circ} \mathrm{C}$, the onset shrinkage temperature of the anode substrate (Fig. 6a). The significant mismatch of the $\mathrm{T}_{\text {Shrinkage }}$ and $\mathrm{T}_{\text {Shrinkage rate }}$ between the SDC600 electrolyte layer and anode substrates would result in a very large tensile stress on the thin electrolyte layer, leading to the delamination and peeling off of the SDC electrolyte layer from the anode substrate. In the case of SDC800, the $\mathrm{T}_{\text {Shrinkage }}$ and $\mathrm{T}_{\text {Shrinkage rate }}$ of the SDC electrolyte layer are 645 and $992^{\circ} \mathrm{C}$, respectively, which are higher than that of SDC600 but still lower than that of anode substrates. Due to the reduced differences of the $\mathrm{T}_{\text {Shrinkage }}$ and $\mathrm{T}_{\text {Shrinkage rate }}$ of SDC800 electrolyte and anode substrates, the internal stress within SDC800 electrolyte layer due to the early shrinkage of the SDC layer would not be high enough to delaminate but is sufficient to deform/bend the anode substrates, as indicated by the curved bilayer structure (Fig.7). For the cell with the SDC1000 electrolyte layer, the $\mathrm{T}_{\text {Shrinkage }}$ of SDC electrolyte is $843^{\circ} \mathrm{C}$, slightly lower than $920^{\circ} \mathrm{C}$ of anode substrate while the $\mathrm{T}_{\text {Shrinkage rate }}$ of SDC electrolyte layer is $1258^{\circ} \mathrm{C}$, close to $1200^{\circ} \mathrm{C}$ of the anode substrates. The close matching of both the onset shrinkage and maximum shrinkage rate temperatures between the SDC electrolyte layer and anode substrate minimizes the internal stress during the co-sintering process. This is supported by the observed flat anode-SDC bilayer cells with SDC1000 electrolyte thin layer (Fig. 7). As shown in Table 1, the differences of the linear shrinkage percentage between 
SDC1000 and anode substrate is $6.4 \%$, higher than that of the SDC800 and SDC600. This indicates that the most important parameters for the structure integrity and flatness of the anode-supported SDC thin electrolyte cells are the matching of the onset shrinkage temperature and the maximum shrinkage rate temperature.

Fig. 9 is the SEM micrographs of the surface of SDC electrolyte films on the anode substrate after co-sintering. All the SDC films have similar grain size in the range of 0.7-1.4 $\mu \mathrm{m}$. Defects such as cracks and pinholes were observed on the electrolyte surface and the degree and number of defects decrease significantly as the calcination temperature of starting SDC powder increases. There was significant formation of cracks and pinholes on the SDC600 electrolyte surface (Fig. 9a) and on the SDC1000 electrolyte surface only isolated pinholes were observed (Fig. 9c). The magnitude of the formation of defects is closely related to the matching of the sintering profile (i.e., the sintering parameters as discussed above) between the SDC electrolyte layer and the underneath anode substrate. The sintering of primary particles in agglomerates at the early stage of sintering will leave pores between agglomerates, leading to inhomogeneous microstructure. In addition, the tensile stress on the electrolyte film due to the mismatching of the onset shrinkage temperature and maximum shrinkage rate temperature between the SDC electrolyte layer and the anode substrate would hinder the sintering of the electrolyte and thereby decrease the sintered density of the electrolyte film. As the calcination temperature of SDC powders increases, the tendency of agglomeration decreases and the sintering mismatch problem of the bilayer can be mitigated.

\subsection{Cell performance}


To address the application the SDC electrolyte films in SOFC, BSCF cathodes were prepared on the anode-supported SDC800 and SDC1000 thin electrolyte films to form single cells. The performance of the cells is shown in Fig. 10. The open-circuit voltages (OCVs) of the cell with the SDC800 film are $0.85,0.83,0.82$ and $0.78 \mathrm{~V}$ at 500, 550, 600 and $650{ }^{\circ} \mathrm{C}$, respectively. Under the same testing conditions, the OCVs of the cell with the SDC1000 film are 0.87, 0.85, 0.84 and $0.79 \mathrm{~V}$ at 500, 550, 600 and $650{ }^{\circ} \mathrm{C}$, respectively. The OCVs are lower than the predicted theoretical values because of the internal shorting caused by the electronic conductivity of the ceria electrolyte [43]. However, the OCVs of $0.82-0.84 \mathrm{~V}$ at $600^{\circ} \mathrm{C}$ in the present work are close to those of the cells with dense ceria films reported in the literatures $[15,17,43]$. The high OCV indicates that the pinholes on the electrolyte surface of the SDC800 and SDC1000 electrolyte films (Fig. 9) are most likely close-end holes and are not across the film. The power density of the cell with the SDC800 electrolyte film is slightly higher than that of the cell with the SDC1000 electrolyte layer. The maximum power densities of the cell based on the SDC800 electrolyte are $1.39,0.99,0.59$ and $0.31 \mathrm{~W} \mathrm{~cm}^{-2}$ at $650,600,550$ and $500^{\circ} \mathrm{C}$, respectively, while the maximum power densities of the cell with SDC1000 electrolyte are $1.28,0.94,0.55$ and $0.30 \mathrm{~W} \mathrm{~cm}^{-2}$ at $650,600,550$ and $500^{\circ} \mathrm{C}$, respectively. The short-circuit current $\left(I_{s}\right)$ of the cell based on the SDC800 electrolyte is also larger than that of the cell based on the SDC1000 electrolyte. For example, the $I_{S}$ of the SDC800 cell at $650{ }^{\circ} \mathrm{C}$ is $5.65 \mathrm{~A} \mathrm{~cm}^{-2}$, which is higher than $4.57 \mathrm{~A} \mathrm{~cm}^{-2}$ of the SDC1000 cell.

Fig. 11 shows the SEM micrographs of the cross-sections of the cells with SDC800 and SDC1000 electrolyte layers. Both the SDC electrolyte layers were $12 \mu \mathrm{m}$ thick, appear dense and adhere well to the porous Ni/SDC anode substrate. The Ni/SDC anode 
substrates appear to be porous and there are no discernable differences between the anode substrates in these two cells.

The electrode overpotential of both anode and cathode could be obtained by subtracting the $i R$ loss from the I-V curves, in which the ohmic resistance of the cell was obtained from the high-frequency intercept of the impedance responses under open-circuit. Fig. 12 shows the $i R$ loss and overpotential curves of the cells as a function of current density. There are significant differences in the $i R$ loss of these two cells. The ohmic resistances of the cell with the SDC800 electrolyte layer are 0.030 and $0.049 \Omega$ $\mathrm{cm}^{2}$ at 650 and $600{ }^{\circ} \mathrm{C}$, respectively, smaller than 0.049 and $0.081 \Omega \mathrm{cm}^{2}$ of the cell with the SDC1000 electrolyte layer. Considering the same electrolyte film thickness of the two cells (Fig. 11), the smaller ohmic resistance of the SDC8 film may be due to the more intimate and good contact at the anode/electrolyte interface. Since the sintering shrinkage of the SDC800 electrolyte layer is larger than that of the SDC1000 electrolyte layer and the anode substrate, the compressive stress on the anode substrate would be likely larger during the co-sintering process, which could be beneficial to achieve a better contact between the electrolyte layer and the anode substrate and thereby a lower ohmic resistance. The overpotentials of the cells with SDC800 and SDC1000 are almost identical, which in turn indicates that performance difference between these two cells is primarily due to the iR losses of the cells

Fig. 13 shows the impedance responses of two cells measured under open-circuit. The electrode polarization resistances $\left(R_{E}\right)$ of the cell with the SDC800 electrolyte film are 0.046 and $0.095 \Omega \mathrm{cm}^{2}$ at 650 and $600{ }^{\circ} \mathrm{C}$, respectively, slightly higher than 0.043 and $0.070 \Omega \mathrm{cm}^{2}$ of the cell with the SDC1000 electrolyte film. The difference of the $R_{E}$ is mostly caused by the difference in the low frequency impedance arc. According to 
McIntosh et al. [44], the low-frequency impedance of a cell most likely represents the contributions of the anode reactions in the case of anode-supported cells. The change in the low-frequency impedance arc demonstrates that the better match of the sintering profiles between the electrolyte layer and anode substrate could also lead to enhanced activities for the oxidation reactions of hydrogen at the electrolyte and anode interface.

In the present study, the sintering profile of the Ni/SDC anode substrates was kept the same while the characteristics of SDC electrolyte layers were altered by calcination temperatures and ball milling treatment. The results clearly indicate that there is close correlation between the characteristics of the SDC powders and the matching of the sintering profile of the Ni/SDC anode substrate and SDC electrolyte layer. For the SDC powder calcined at $600^{\circ} \mathrm{C}$, SDC600, both onset sintering temperature and maximum sintering rate temperatures were significantly lower than that of anode substrates, which caused the delamination of the electrolyte and anode substrates. Increasing the calcination temperature increased both onset sintering and maximum sintering rate temperatures and better matching of the sintering profiles between the anode substrates and SDC electrolyte layers was obtained on the cells with SDC powder calcined at $1000^{\circ} \mathrm{C}$, SDC1000. The cells with SDC1000 not only showed flatness of the SDC-Ni/SDC bilayer structure after co-sintering, but also good performance at intermediate temperatures of 500 to $650^{\circ} \mathrm{C}$ (see Fig. 10).

\section{Conclusions}

The characteristics of SDC powders calcined at different temperatures and their effects on the fabrication, microstructure and performance of anode-supported SDC electrolyte thin film cells have been studied. Based on the XRD, TEM, SEM and particle size distribution results, SDC powders synthesized by the GNP method are 
characterized by nano-sized powders, which form foam-like and highly porous agglomerates. Both calcination temperature and mechanical ball-milling have significant effect on the size and distribution of the SDC agglomerates. The sintering profiles of the SDC electrolyte layers are significantly affected by the calcination temperature of the powder. The coherence between the bilayer and the sintered density of SDC film and the flatness of the cells strongly depend on the matching in the shrinkage behaviors such as the onset sintering temperature, linear shrinkage percentage and the maximum sintering rate temperature between the SDC electrolyte layer and anode substrate. Dense SDC electrolyte layer and flat anode supported SDC thin electrolyte cells with high performance at intermediate temperatures of $500-650^{\circ} \mathrm{C}$ were achieved using the SDC powder calcined at $1000^{\circ} \mathrm{C}$. The results in this study demonstrate the importance of the characteristics of SDC electrolyte powder in the development of anode supported SDC thin electrolyte cells with good cell flatness and high power output under IT-SOFC operation conditions.

\section{Acknowledgement}

This work is partially supported by the Australia Research Council (LP110200281), Australia.

\section{References}

1. F. L. Liang, J. Chen, S. P. Jiang, B. Chi, J. Pu, L. Jian, Electrochem. Solid State Lett. 11 (2008) B213-B16.

2. F. L. Liang, J. Chen, S. P. Jiang, F. Z. Wang, B. Chi, J. Pu, L. Jian, Fuel Cells 9 (2009) 636-42.

3. B. Hua, J. Pu, J. Zhang, F. Lu, B. Chi, L. Jian, J. Electrochem. Soc. 156 (2009) B93-B98.

4. $\quad$ S. Sang, W. Li, H. Pu, L. Han, J. Power Sources 177 (2008) 77-82. 
5. S. P. S. Badwal, Solid State Ionics 52 (1992) 23-32.

6. T. Ishihara, T. Shibayama, M. Honda, H. Nishiguchi, Y. Takita, Chem. Commun. (1999) 1227-28.

7. B. C. H. Steele, Solid State Ionics 129 (2000) 95-110.

8. D. Beckel, A. Bieberle-Hutter, A. Harvey, A. Infortuna, U. P. Muecke, M. Prestat, J. L. M. Rupp, L. J. Gauckler, J. Power Sources 173 (2007) 325-45.

9. L. C. De Jonghe, C. P. Jacobson, S. J. Visco, Annual Review of Materials Research 33 (2003) 169-82.

10. A. Evans, A. Bieberle-Hutter, J. L. M. Rupp, L. J. Gauckler, J. Power Sources 194 (2009) 119-29.

11. J. Will, A. Mitterdorfer, C. Kleinlogel, D. Perednis, L. J. Gauckler, Solid State Ionics 131 (2000) 79-96.

12. T. S. Zhang, J. Ma, L. H. Luo, S. H. Chan, Journal of Alloys and Compounds 422 (2006) 46-52.

13. J. W. Fergus, J. Power Sources 162 (2006) 30-40.

14. C. R. Xia, F. L. Chen, M. L. Liu, Electrochem. Solid State Lett. 4 (2001) A52-A54.

15. C. R. Xia, M. L. Liu, J. Am. Ceram. Soc. 84 (2001) 1903-05.

16. Y. J. Leng, S. H. Chan, S. P. Jiang, K. A. Khor, Solid State Ionics 170 (2004) 9-15.

17. Z. P. Shao, S. M. Haile, Nature 431 (2004) 170-73.

18. N. Oishi, A. Atkinson, N. P. Brandon, J. A. Kilner, B. C. H. Steele, J. Am. Ceram. Soc. 88 (2005) 1394-96.

19. Q. L. Liu, K. A. Khor, S. H. Chan, J. Power Sources 161 (2006) 123-28.

20. Y. H. Zhang, X. Q. Huang, Z. Lu, Z. G. Liu, X. D. Ge, J. H. Xu, X. S. Xin, X. Q. Sha, W. H. Su, J. Power Sources 160 (2006) 1217-20.

21. N. Ai, Z. Lu, K. F. Chen, X. Q. Huang, B. Wei, Y. H. Zhang, S. Y. Li, X. S. Xin, X. Q. Sha, W. H. Su, J. Power Sources 159 (2006) 637-40.

22. Y. D. Zhen, A. I. Y. Tok, S. P. Jiang, F. Y. C. Boey, J. Power Sources 178 (2008) 69-74.

23. S. P. Jiang, S. H. Chan, J. Mater. Science 39 (2004) 4405-39.

24. J. J. Haslam, A. Q. Pham, B. W. Chung, J. F. DiCarlo, R. S. Glass, J. Am. Ceram. Soc. 88 (2005) 513-18.

25. W. T. Bao, Q. B. Chang, G. Y. Meng, Journal of Membrane Science 259 (2005) 103-09.

26. J. Y. Hu, Z. Lu, K. F. Chen, X. Q. Huang, N. Ai, X. B. Du, C. W. Fu, J. M. Wang, W. H. Su, Journal of Membrane Science 318 (2008) 445-51.

27. P. Von Dollen, S. Barnett, J. Am. Ceram. Soc. 88 (2005) 3361-68.

28. Y. H. Zhang, X. Q. Huang, Z. Lu, Z. G. Liu, X. D. Ge, J. H. Xu, X. S. Xin, X. Q. Sha, W. H. Su, J. Power Sources 160 (2006) 1065-73.

29. K. F. Chen, X. J. Chen, Z. Lu, N. Ai, X. Q. Huang, W. H. Su, Electrochimica Acta 54 (2009) 1355-61.

30. Z. Cai, T. N. Lan, S. Wang, M. Dokiya, Solid State Ionics 152-153 (2002) 
583-90.

31. J. M. Wang, Z. Lu, K. F. Chen, X. Q. Huang, N. Ai, J. Y. Hu, Y. H. Zhang, W. H. $\mathrm{Su}$, J. Power Sources 164 (2007) 17-23.

32. Y. J. Leng, S. H. Chan, K. A. Khor, S. P. Jiang, P. Cheang, J. Power Sources 117 (2003) 26-34.

33. Y. R. Wang, T. Mori, J. G. Li, T. Ikegami, Y. Yajima, Journal of Materials Research 18 (2003) 1239-46.

34. N. Ai, Z. Lu, K. F. Chen, X. Q. Huang, Y. W. Liu, R. F. Wang, W. H. Su, Journal of Membrane Science 286 (2006) 255-59.

35. J. H. Song, S. I. Park, J. H. Lee, H. S. Kim, Journal of Materials Processing Technology 198 (2008) 414-18.

36. L. A. Chick, L. R. Pederson, G. D. Maupin, J. L. Bates, L. E. Thomas, G. J. Exarhos, Materials Letters 10 (1990) 6-12.

37. K. F. Chen, Z. Lu, X. J. Chen, N. Ai, X. Q. Huang, B. Wei, J. Y. Hu, W. H. Su, Journal of Alloys and Compounds 454 (2008) 447-53.

38. W. D. Kingery, H. K. Bowen, D. R. Uhlmann, (John Wiley and Sons, New York, 1976), pp. 522.

39. S. Lü, G. Long, Y. Ji, X. Meng, C. Sun, International Journal of Hydrogen Energy 35 (2010) 7930-35.

40. X. S. Xin, Z. Lu, X. Q. Huang, X. Q. Sha, Y. H. Zhang, K. F. Chen, N. Ai, R. B. Zhu, W. H. Su, J. Power Sources 160 (2006) 1221-24.

41. X. S. Xin, Z. Lu, B. B. Zhou, X. Q. Huang, R. B. Zhu, X. Q. Sha, Y. H. Zhang, W. H. Su, Journal of Alloys and Compounds 427 (2007) 251-55.

42. J. Ma, L. C. Lim, Journal of the European Ceramic Society 22 (2002) 2197-208.

43. X. Zhang, M. Robertson, C. Deces-Petit, W. Qu, O. Kesler, R. Maric, D. Ghosh, J. Power Sources 164 (2007) 668-77.

44. S. McIntosh, J. M. Vohs, R. J. Gorte, J. Electrochem. Soc. 150 (2003) A1305-A12. 
Table 1. Sintering shrinkage parameters of the SDC powders and anode substrate from 50 to $1300^{\circ} \mathrm{C}$.

\begin{tabular}{|c|c|c|c|c|c|}
\hline Samples & $\begin{array}{l}\text { Calcination } \\
\text { temperature } \\
\left({ }^{\circ} \mathrm{C}\right)\end{array}$ & $\begin{array}{l}\text { Shrinkage } \\
\text { onset } \\
\text { temperature } \\
\left({ }^{\circ} \mathrm{C}\right)\end{array}$ & $\begin{array}{l}\text { Temperature } \\
\text { at maximum } \\
\text { shrinkage } \\
\text { rate }\left({ }^{\circ} \mathrm{C}\right)\end{array}$ & $\begin{array}{l}\text { Maximum } \\
\text { shrinkage } \\
\text { rate } \\
\left(\% \mathrm{~min}^{-1}\right)\end{array}$ & $\begin{array}{c}\text { Linear } \\
\text { shrinkage } \\
(\%)\end{array}$ \\
\hline SDC600 & 600 & 556 & 887 & -0.40 & -13.3 \\
\hline SDC800 & 800 & 645 & 992 & -0.32 & -10.8 \\
\hline SDC1000 & 1000 & 843 & 1258 & -0.35 & -7.6 \\
\hline Anode & 950 & 920 & 1200 & -0.59 & -14.0 \\
\hline
\end{tabular}




\section{Figure captions}

1. XRD patterns of SDC powders calcined at (a) 600 , (b) 800 and (c) $1000{ }^{\circ} \mathrm{C}$

2. TEM micrographs of SDC powders calcined at (a) 600 , (b) 800 and (c) $1000^{\circ} \mathrm{C}$.

3. SEM micrograph of as prepared SDC powder after calcined at $800^{\circ} \mathrm{C}$ without ball milling.

4. Particle size distributions of SDC calcined at $800^{\circ} \mathrm{C}$ as a function of ball-milling time.

5. Particle size distributions of SDC powders with different calcination temperatures after ball milling for $20 \mathrm{~h}$.

6. Plots of (a) sintering shrinkage and (b) shrinkage rate of SDC powders and anode substrate samples. The SDC powders were ball-milled for $20 \mathrm{~h}$ before the TGA measurements?

7. Optical micrographs of anode-supported SDC thin electrolyte cells with SDC electrolyte layers. SDC electrolytes were prepared from SDC powders calcined at different temperatures.

8. Relationship between the sintering parameters and the morphology and flatness of the anode-supported SDC electrolyte cells.

9. Micrographs of the surface of electrolyte films made from the SDC powders calcined at (a) 600, (b) 800 and (c) $1000{ }^{\circ} \mathrm{C}$. All the powders were ball milled for $20 \mathrm{~h}$ before the film fabrication.

10. Performance curves of cells with SDC electrolyte films prepared from SDC powders calcined at (a) 800 and (b) $1000{ }^{\circ} \mathrm{C}$. Dry hydrogen at a flow rate of $40 \mathrm{~mL}$ $\min ^{-1}$ was fed to the anodes and the stationary air was used as the oxidant.

11. Micrographs of cross-sections of Ni-SDC anode supported cells with the SDC 
powder calcined at (a) 800 and (b) $1000{ }^{\circ} \mathrm{C}$.

12. Electrode overpotentials and ohmic loss of the cells at (a) 650 and (b) $600{ }^{\circ} \mathrm{C}$.

13. Impedance responses of the cells measured under open-circuit conditions at (a) 650 and (b) $600{ }^{\circ} \mathrm{C}$. The SDC powders were calcined at 800 and $1000{ }^{\circ} \mathrm{C}$. The ohmic contribution has been removed in the figures. 
Figure 1.

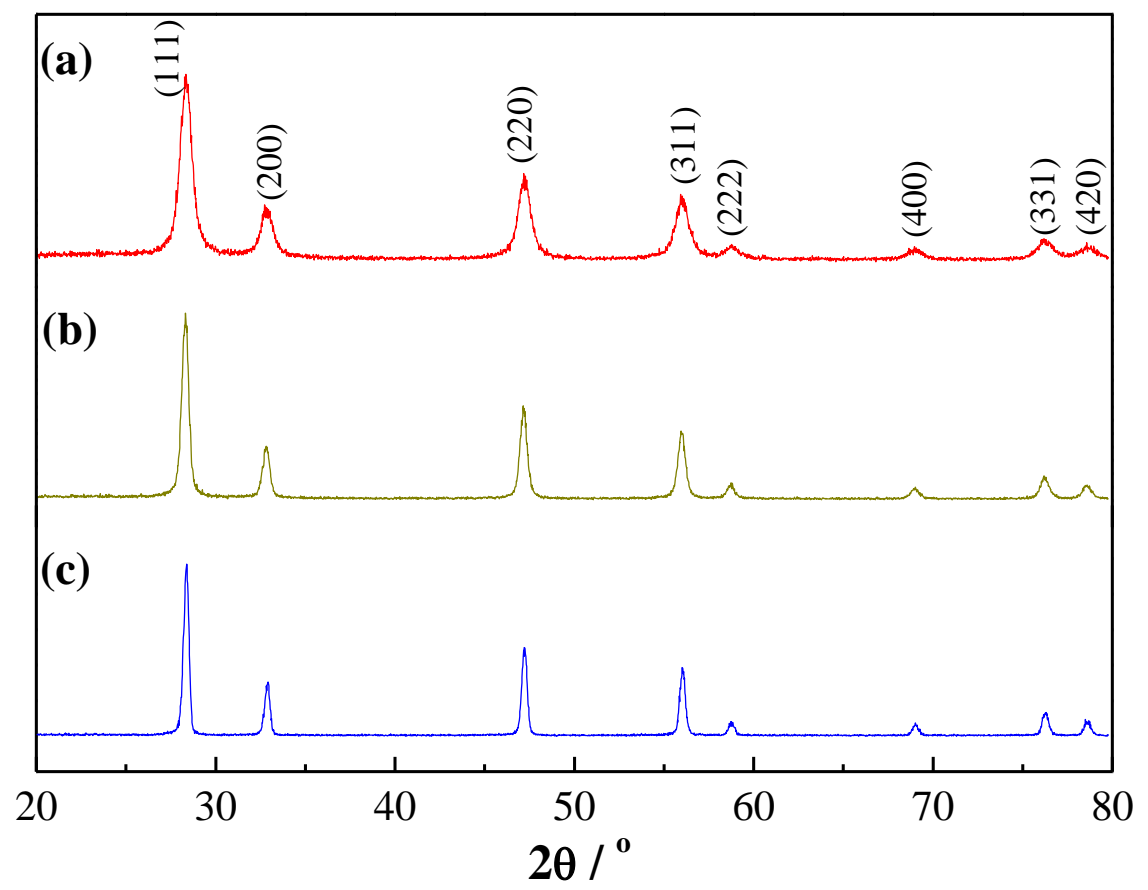


Figure 2.

(a)

(b)
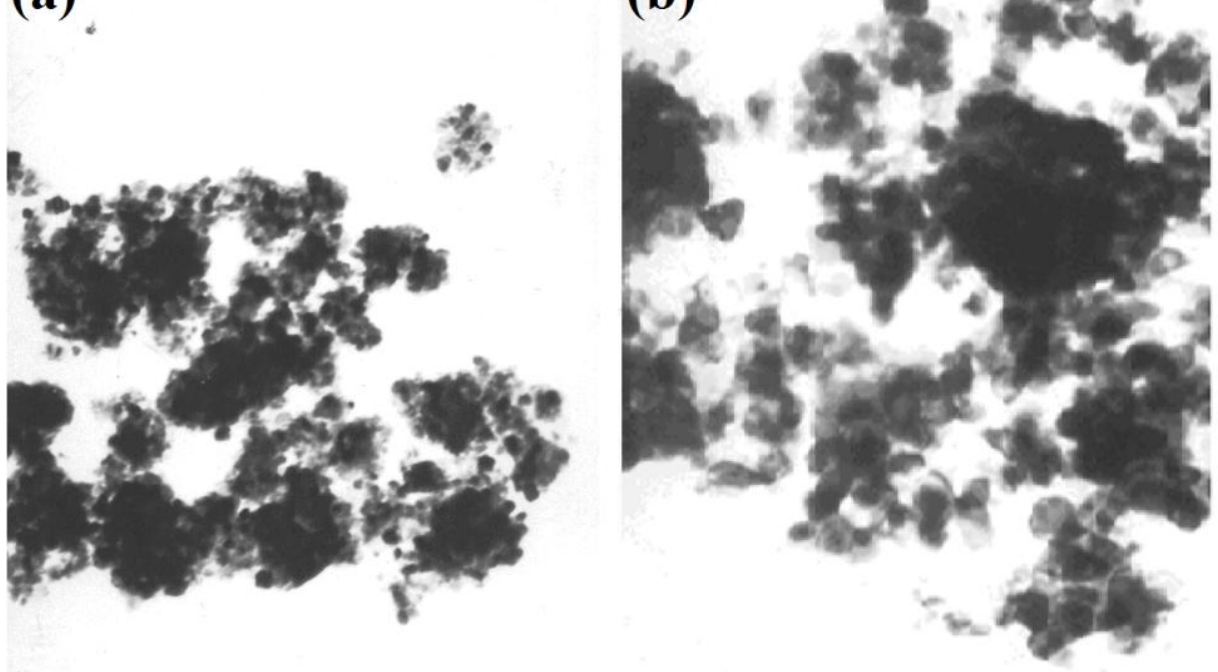

5 59n

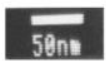

(c)
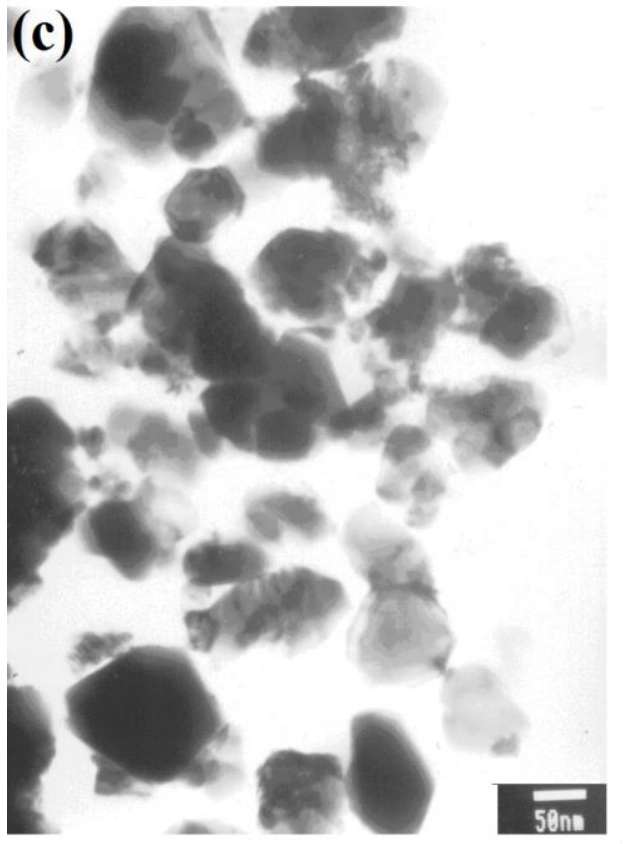
Figure 3.

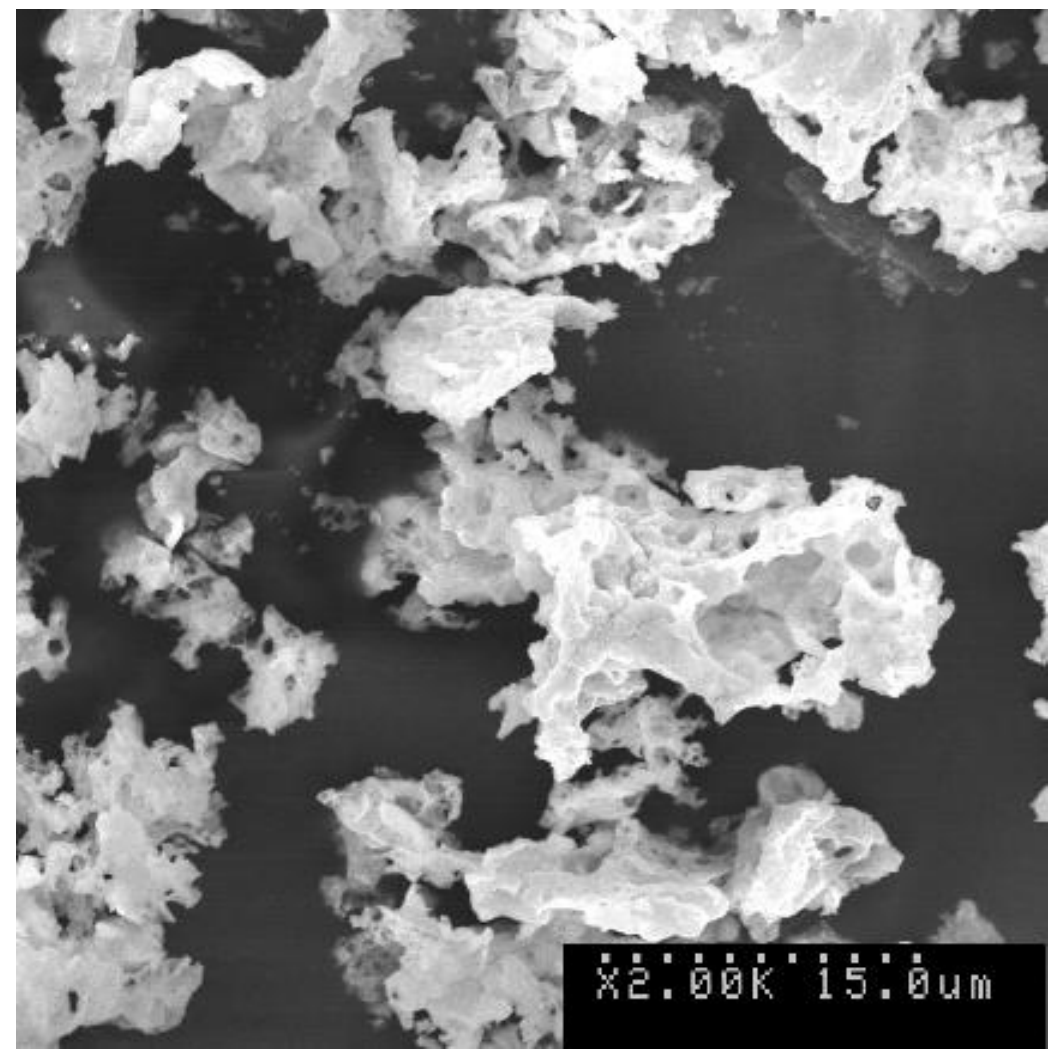


Figure 4.

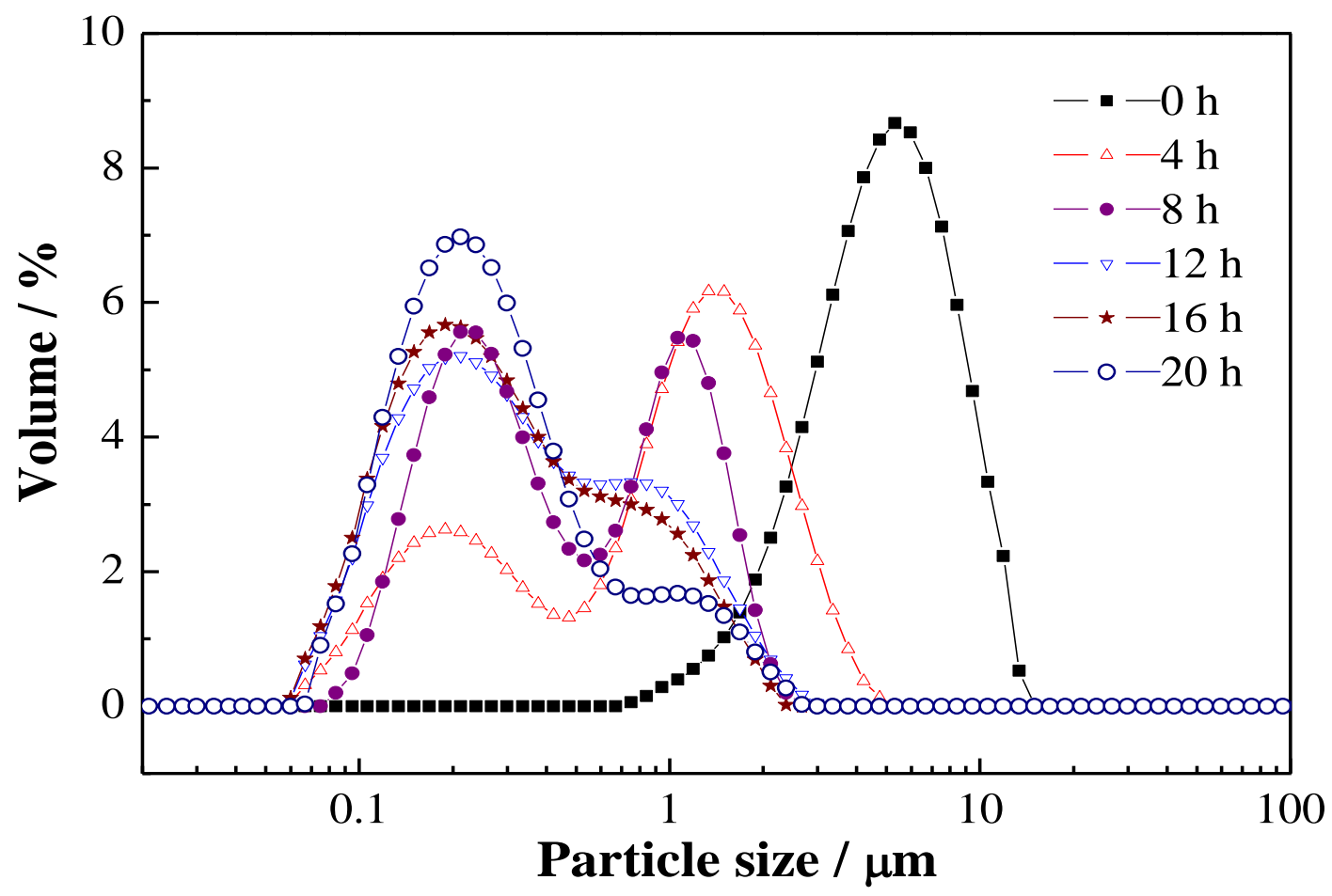


Figure 5.

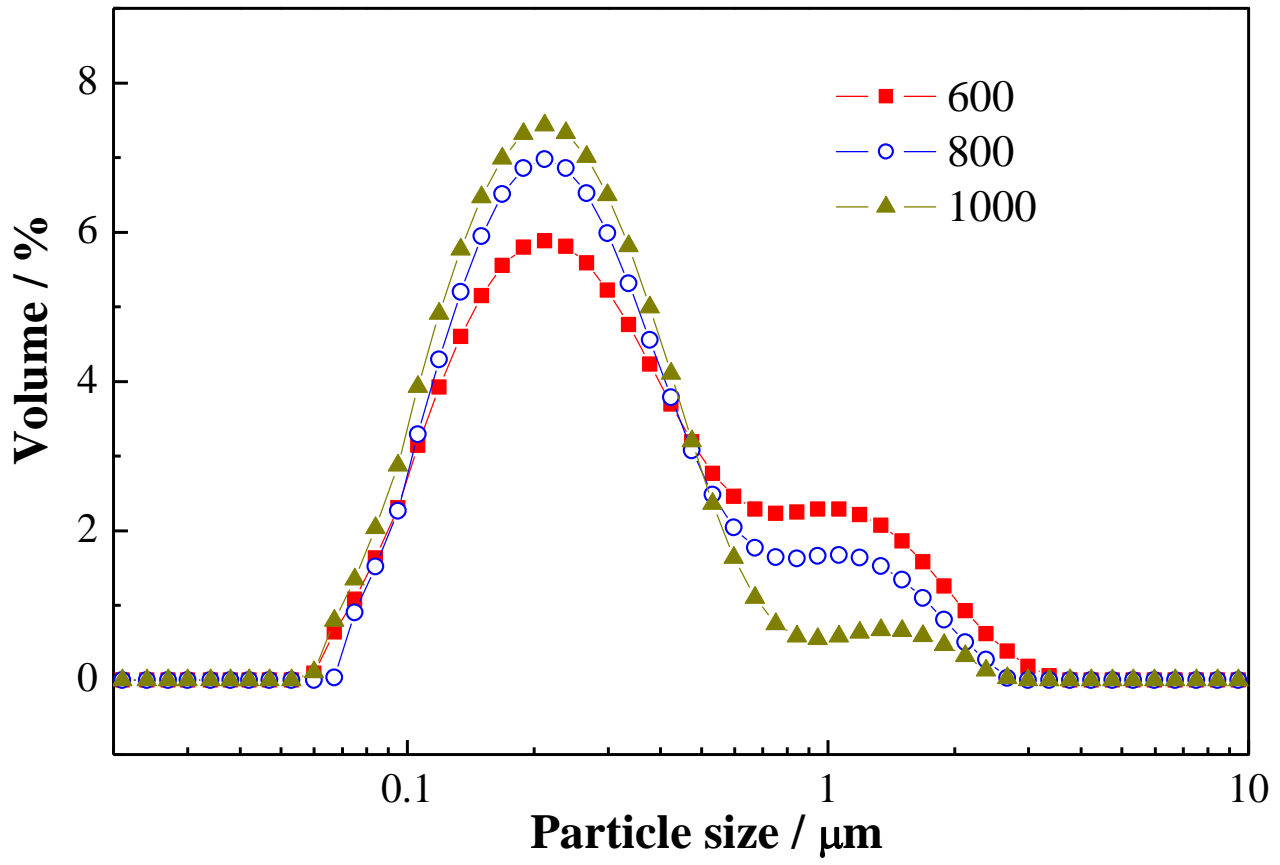


Figure 6.
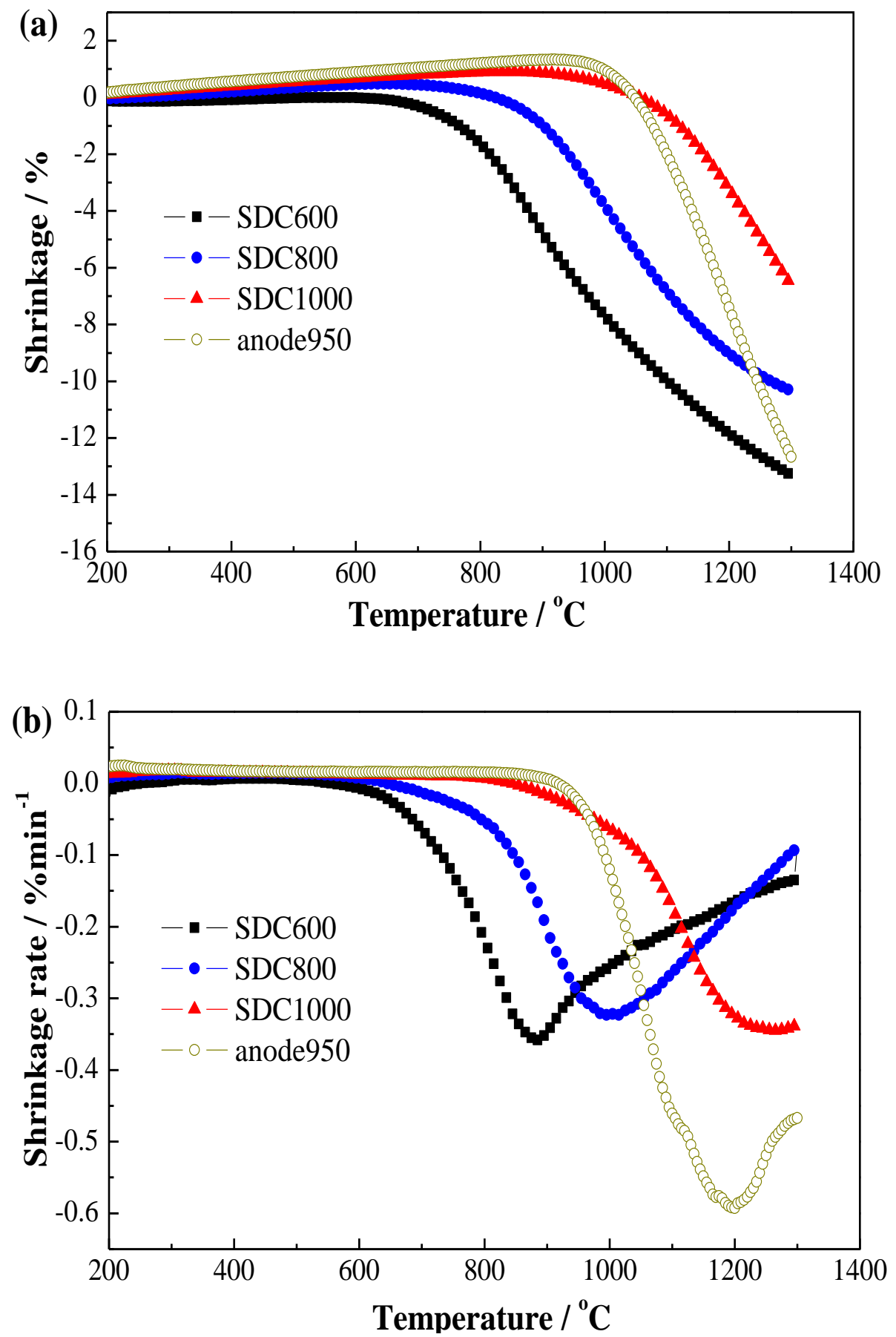
Figure 7.

SDC600

SDC800 SDC1000

$10 \mathrm{~mm}$ 
Figure 8

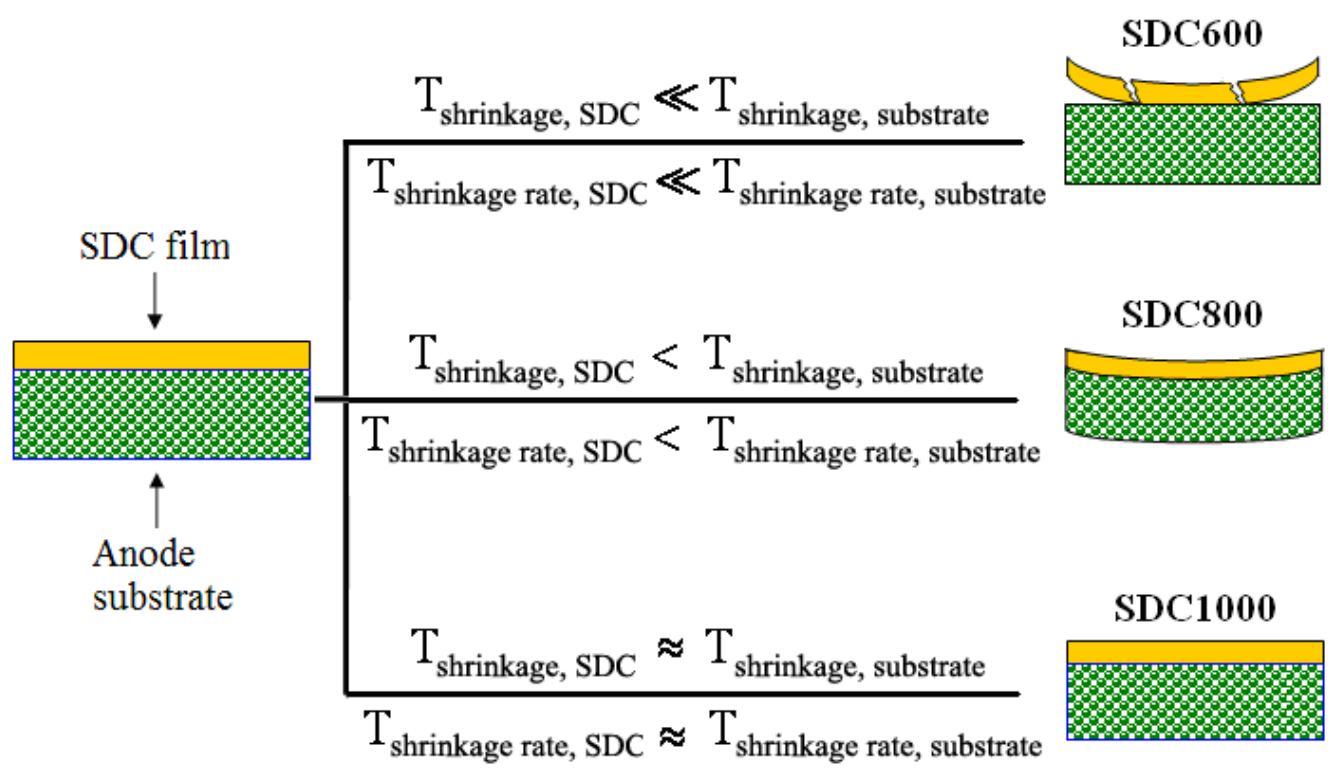


Figure 9
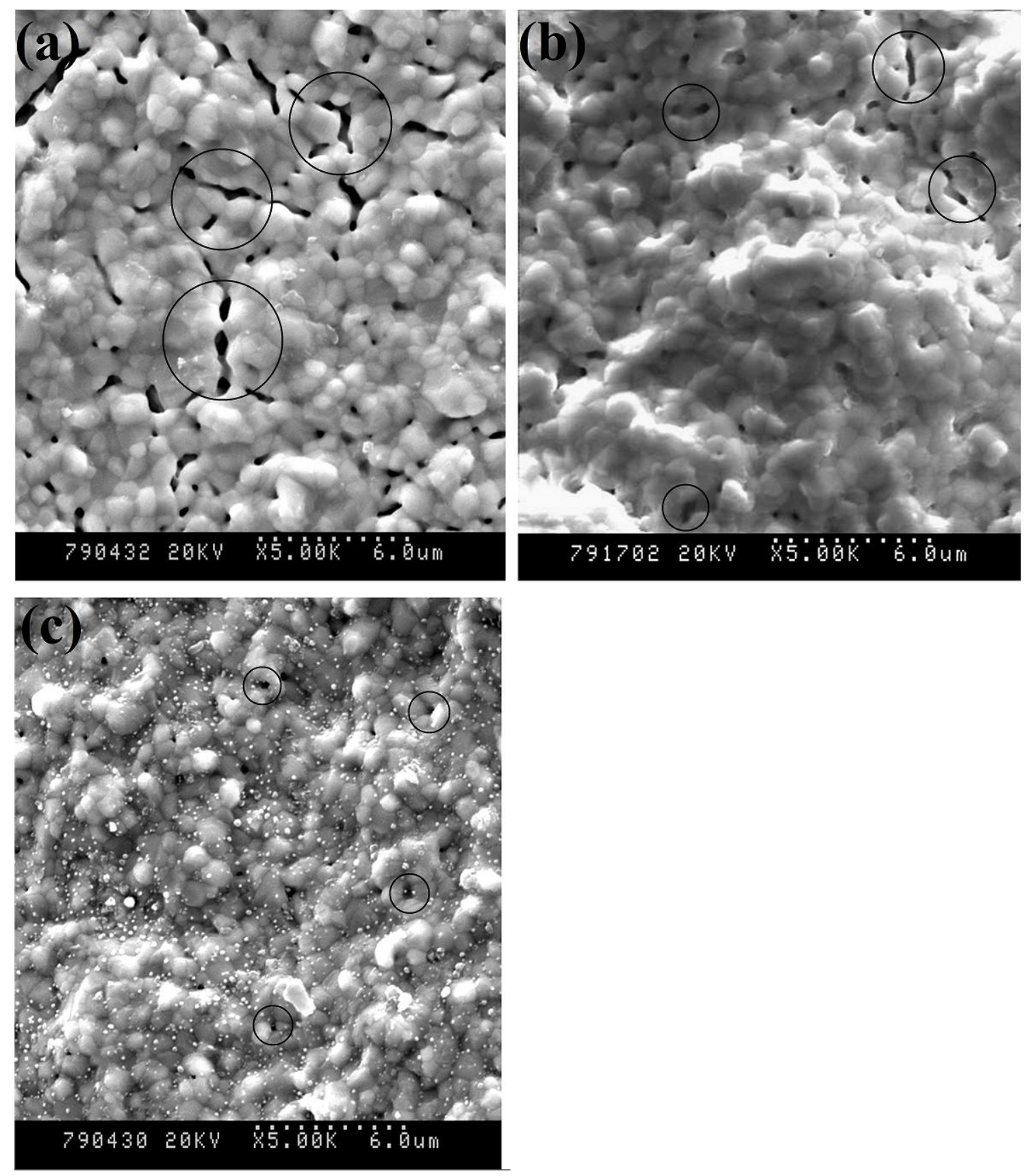
Figure 10
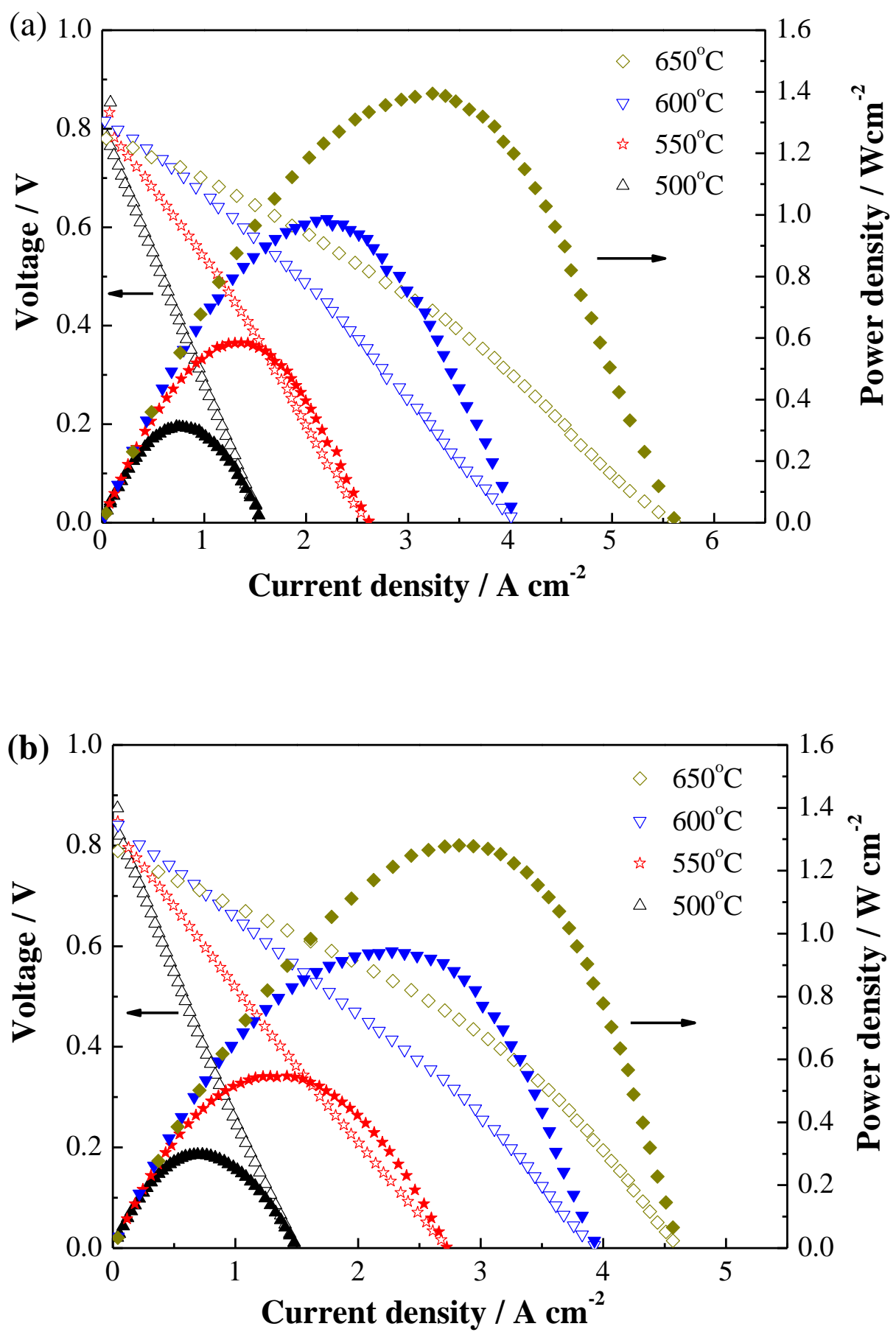
Figure 11.
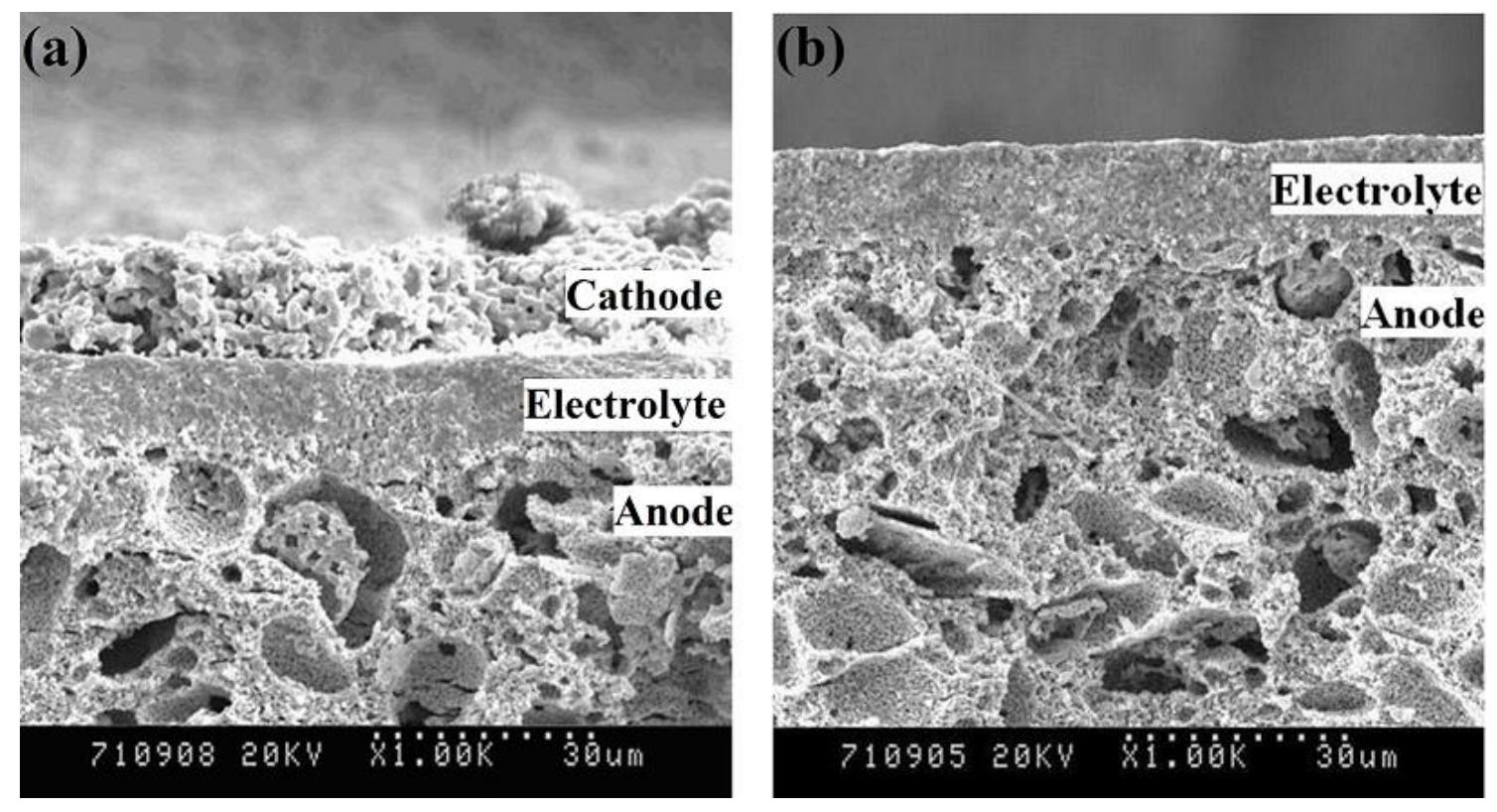
Figure 12.
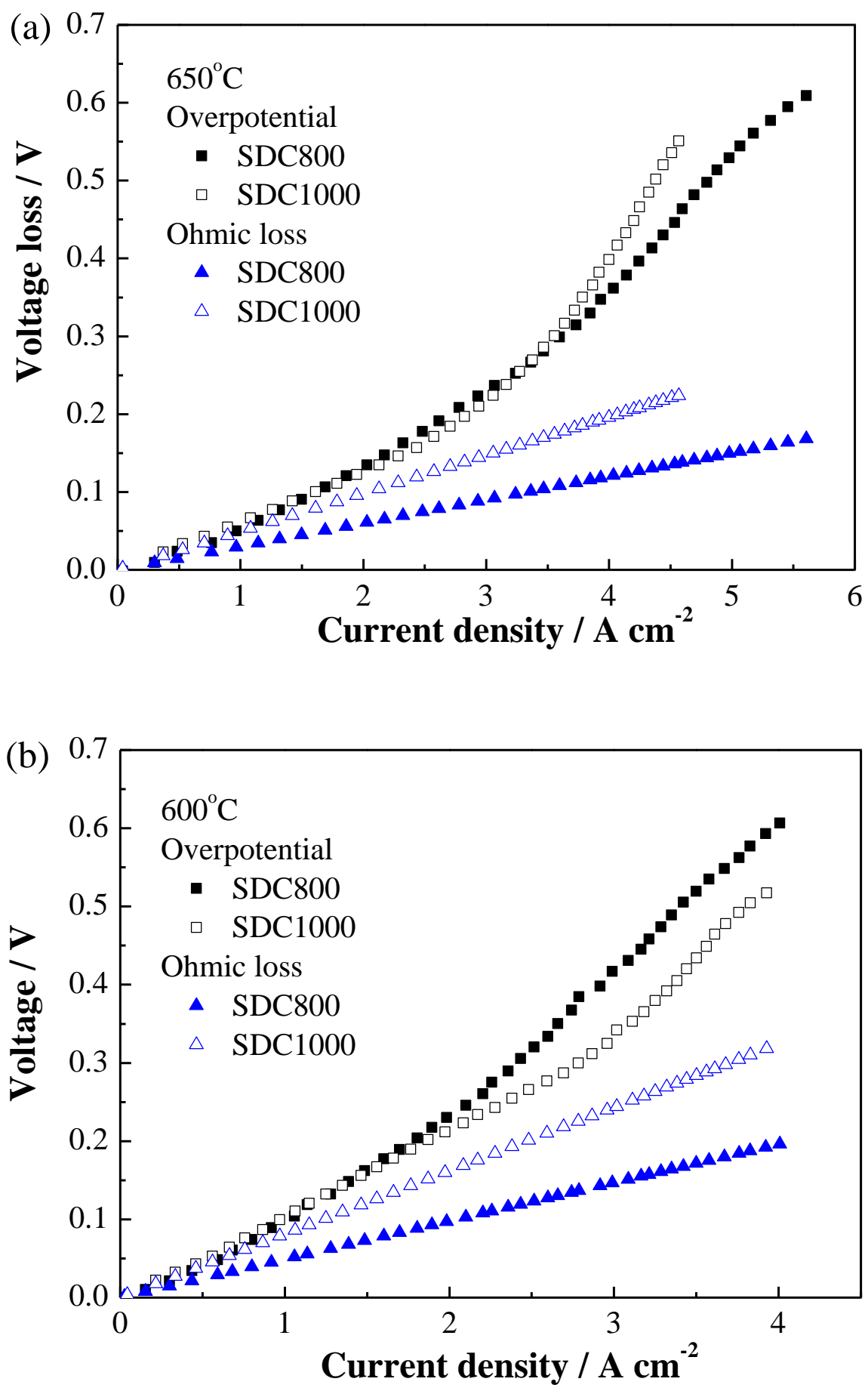
Figure 13.
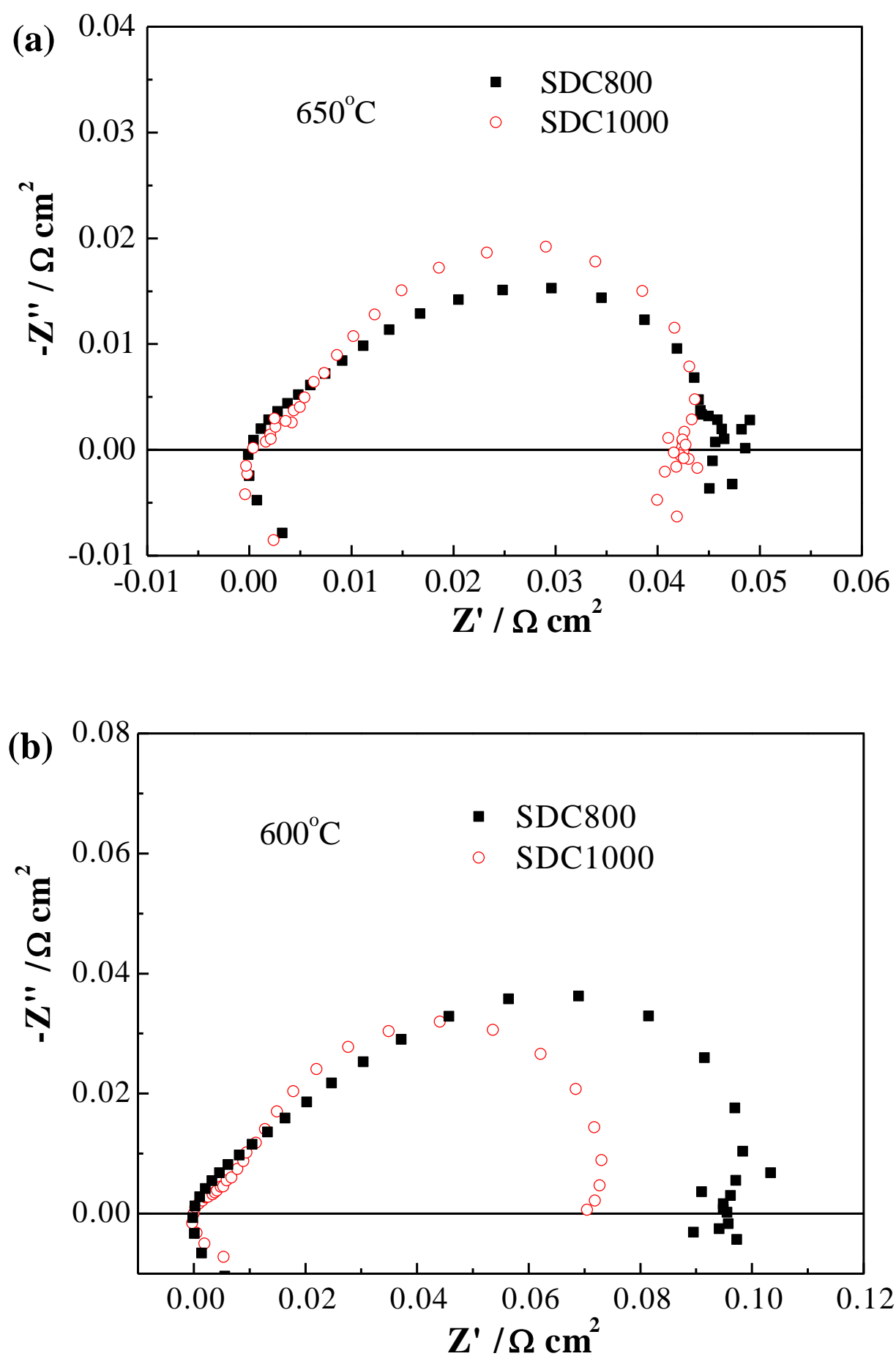